\title{
The Principles and the Ways of Classroom Interaction
}

\author{
Keqing Chai \\ school of foreign languages \\ Jiujiang University \\ Jiujiang, China 332005 \\ e-mail:ckqaie@126.com
}

\begin{abstract}
This article explores, from the perspective of educational philosophy, the development of the theories "teacher centered theory", "student centered theory", the double -subject theory and the theory of intersubjectivity, and puts forward some ways and principles of the implementation of classroom interaction under the guidence of the philosophy of intersubjectivity.
\end{abstract}

Keywords—classroom teaching; positive interaction; intersubjectivity

\section{ISSUES RAISED}

The process of teaching, is the process of interaction between teachers and students, and also between the students themselves. The ways and efficiency of the interaction between the teachers and students or between the students and students, will determine the success or failure of the teaching. Because of our job, the author in the past five years have visited the university classroom or attended more than 40 university classroom lectures. From all these lectures I have come to the conclusion that the classroom interaction between teachers and students is much better than the people thought of in the past. They thought in the past years a university teacher was just holding a book in the classroom teaching, copiously and fluently delivering their speech for two hours, and then sped away. Now the reality is that teachers have obviously begun to attach more importance to the interaction with students. But there are many problems as follows:

- More and more interactions between teachers and students appear in the classroom but the interactions between students and students has not started yet;

- Teachers are always dominant in the teacher-student interaction, the students are usually passive and unactive. The time of the interaction, when to begin the interaction, the interactive content, the interactive way, and when to end the interaction are strictly controlled by the teacher, not by the students or by both. The students just give the answer to the questions and react to the requirements of the teacher;

- The interactions between teachers and students do not cover enough students, which most of the time is confined only to those active students about one third, most of the students are not involved in the interaction;
These problems seem to be ingrained, the teachers always think that there is no way to solve the problems. We might as well put aside the specific problems to analyze the value orientation of the classroom interaction from the angle of philosophy.

\section{ANALYSIS OF CLASSROOM INTERACTION IN PHILOSOPHY}

Classroom interactions, especially the study of the interaction between teachers and students are mainly influenced by subject and object theory, double-subject theory and intersubjectivity theory in philosophy. Their developments have gone through four stages:

\section{A. The teacher-centered stage}

The traditional classroom teaching usually follows Herbart's "class teaching" theory. Under the advocacy of Herbart, the father of modern education, modern education is on the way to do teaching on the basic unit: class, the formal school unit. From that time on the teaching activities occur in the classroom At that time the European classroom arrangement is like that in most of our school in our country: the teacher's desk is right in the front of the classroom, the desks and chairs of the students are neatly laid out row upon row in the rest space of the classroom. The teacher in the front speaks with fervour and assurance, the students seriously take notes and do the exercises in class. The teacher is the center or core of the class, making a decision about teaching contents and the students' learning process, and he is also the teaching and learning evaluator. Students are passive knowledge container or receivers. There are few classroom interactive activities. The students' initiative, the autonomy of the students, their freedom and rights are neglected.

\section{B. Students-centered stage}

At the beginning of twentieth Century there was an American educator and philosopher Dewey as a representative of the education reformers at that time put forward a new theory "child-centered theory", emphasizing democracy in education : "since in the democratic society we think there is no external authority influence, it must use the voluntary disposition and interest to replace it; and the voluntary tendency and interest can only be formed through education " (Dewey, 2001) The theory "Child -centered 
theory" emphasizes the needs of children and children's growth is the center or goal of the classroom teaching, and the teacher is just an attendant, advisor and assistant. The teacher's role is weakened, or sometimes teachers are just onlookers. The traditional idea of education shifts from one extreme to the opposite extreme. The effect of "Child centered theory" on the Chinese is relatively large. A student of Dewey, the great educator Tao Xingzhi from China was deeply influenced by his theory, Dewey was also invited to China for an academic visit and delivered many lectures in many places for a long time. Tao Xingzhi attached a great importance to democracy in education and democratic education: "democracy and education is to teach people to be the master, to be their own masters, be the masters of the country, to be the masters of the world." (East China Normal University, 1989)

"Child -centered theory" is the reaction to "Teacher centered theory", paying attention to the learners' requirements, focusing on the students' initiative, but on the other hand it ignores the role of teachers. As professional educators, teachers' knowledge, skills, ideas are not fully utilized in the "Child -centered theory" classroom, resulting that the classroom teaching level of each school, each class are uneven, and further more it is not conducive to the students to master the knowledge systematically.

Because the number of the teachers is relatively small, good teachers are still not enough, the class size is relatively large. In rural areas classes over 60 students are still relatively common. And in addition the teacher's dignity" far-reaching influences on Chinese, China currently mainly uses the "Teacher centered theory" classroom teaching.

\section{Dual or double-subject stage}

After the "Teacher- centered theory" and "studentcentered theory", the education sector has proposed the theory that teacher and students both are the subjects of education. The difference between them is that the teacher is a director in teaching and the student is the learning subject. The teacher provides the servises to the students, but the teacher can also use his expertise, skills to determine the learning content, methods and even results. So the development of the educational idea like a pendulum, moving from left to right, now seems to be back to the centre.

This idea is consistent with Chinese philosophy "golden mean", which so far has been endorsed by the mainstream educators of our country. For example, China's well-known education expert Professor Ye Lan thinks that, "in the educational activities, there are two kinds of activities: teaching activities and learning activities. In the teaching activities, educators or teachers are the undertakers of the teaching activities, shaping the students his object to the requirement of education, who are the essential condition in his teaching. On the contrary, in the learning activities, the students are the subjects, educators are one of the necessary conditions of the learning and the object of the learning." (1996) but the theory is also difficult to implement its ideas and methods in the actual classroom teaching .For example, both teachers' teaching and students' learning in most cases occur at the same time in the classroom. If the leading role of the teacher is too much emphasized or powerful, students' subjectivity would be ignored, or even muzzled, and if the students' subjectivity is paid too much attention to in learning, the teachers' leading role in teaching would be overlooked or even inhibited. It is difficult to keep the balance between them .This seems to be a fuzzy thinking, there is no clear principles and feasible way, causing the education practitioners, the majority of the teachers confused. According to my observation, most of the current classroom in our country still lay particular stress on the leading role of teachers and ignore the students' main function, because the students have no other choice but to answer the teachers' questions, do the homework to do assigned by teacher, participate in the examination of teachers. They have no power to make a decision.

\section{The stage of intersubjectivity}

Intersubjectivity is the core category to construct communication theory of the twentieth Century philosophy. The communication of Intersubjectivity is the behavior that "teachers and students reach an understanding and agreement for the purpose through communication. It is mainly through mutual communication and coordination of social conformity to reach an understanding, the formation of non forced consciousness." (Zheng Zhaoli, 2000)

Intersubjectivity theory no longer looks at teachers and students as the two opposite sides, they are equal in the classroom. They have the same goal in education .They can democratically communicate with each other through mutual understanding and dialogue, and at last reach an unforced common consensus about the text, achieving the "fusion of Horizons" and experience sharing.

Intersubjectivity is a new relationship between teachers and students, a new train of thought of classroom interaction, and it is becoming the theoretical foundation of the reform of classroom interaction mode. The students who are enriched with the knowledge, improved with skills, enhanced with the independent consciousness, require classroom teaching to reform, wish to have the respect from the teachers and a dialogue equally with educators.

\section{THE PRINCIPLE OF CLASSROOM INTERACTION UNDER THE GUIDANCE O INTERSUBJECTIVITY}

Intersubjectivity is different from the theory the subject and object of the binary opposition between the two, which puts forward a new view of classroom interaction about the reform of classroom teaching. The author has summarized and come to the conclusion that intersubjectivity classroom should follow at least the following principles:

\section{A. The principle of democracy, equality and interaction}

Only when the teachers and students are willing to be democratic and be a subject and regard each other as the subject, the relationship between teachers and students becomes the relationship of intersubjectivity and the relationship of democracy. (Hao Wenwu, 2009) That is to say both teachers and students have accepted the idea of 
democracy and are willing to respect each other. With this atmosphere, can the inter subjectivity education be gradually established.

The equality and democracy between teachers and students, between students is the basic principle of classroom interaction. In this interaction, the teacher can not impose its will on the students, can not force students to comply with the specification that they don't approve, and students also should not think of themselves as the education customers, the education consumer, ask for too much of the teacher, not even respect the teacher.

\section{B. Listening and understanding}

If only there is equality, democracy in interaction, but in the interaction the two sides have no mutual understanding, have not developed the habit of listening, interaction, also, may lead to self-interaction or talking to oneself, or even become a negative resist.

That the teachers are required to understand the students, is to meet the needs of students in cognition and emotion, Students also should understand the teacher in the need of occupation and emotion, rather than the teacher speaking with fervour and assurance, the student being absent-minded. This is typical performance of the lack of understanding of each other; the teachers ignore students need and students overlook the teachers' feeling. There is almost no interaction in teaching, at least there is no positive interaction.

The habit of listening means mutual understanding, mutual respect. It is not easy to do this, which needs longterm efforts. For example, students can listen to the teacher's wonderful speech, but it is difficult for the teacher to listen to the student's answering intermittently and inaccurately, Let alone request the students to listen to a poor student's ambiguous statement.

\section{Dialogue}

Gregory Bates on said, " the social environment and the way of the transmission of information plays a leading and decisive role in the process of teaching and learning, rather than teaching content." (Bauman, 2002) constructivist thinks that knowledge is the unity of objective reflection and subjective construction, is the result of cognitive subject's active choice, processing and creation to the stimulation . Educators in the new world must turn their attention from the teaching material, the education content to the education mode.

Teachers should communicate with students and students should communicate with students democratically and equally through language. This is a two-way, dynamic generating process of dialogue, rather than teachers explaining strictly on the basis of the teaching plan. Without a sincere dialogue, there is no equal interaction, there is no democracy, let alone mutual understanding between the two sides.

\section{Reaching a consensus as the goal}

Classroom interaction doesn't mean uninterrupted dialogue and negotiation, but the two sides of the interaction with an open mind get out of the original "narrow" horizon fusion, and reach a new consensus on the new horizon, which is on a higher level.

\section{WAYS OF CLASSROOM INTERACTION}

\section{A. Quiz between teachers and students or between students}

To reflect democracy and equality the teachers and students, between students and students, we should first change the way that the teacher asked the students questions and the students answer. Let the students ask questions, ask the teacher questions, ask the other students questions, which allows students to think actively learning content, cultivate their innovative thinking, and can let the student clearly experience their own dominant position, subject consciousness in class, and make the students more like to participate in the teaching content, teaching process, teaching results.

In our teaching practice, it is not a simple task to let the students ask questions. That the students ask questions itself is not easy, to raise a good and worthy question will be more difficult. This requires students not only to know the learning content, but also need more thinking, more practice in life, otherwise it is not a good question.

It is a great challenge for the teacher. Letting the students ask questions increases the unpredictability of the classroom activities and learning content. The teacher can not answer all the questions raised by students. This requires teachers to accept the fact that the teacher's knowledge is limited .which is conducive to the development of students' autonomy and innovation.

\section{B. Keep an eye on students' real needs of learning}

To interact with students equally, to understand students, listen to their quirements and difficulties, we would take care of their real learning needs. Different students have different life experiences and different knowledge backgrounds which determines the learning needs of different students will be various. How to design teaching plan, classroom activities, classroom arrangement and homework the teacher should fully consider the different needs of them, which requires the teacher to make great efforts. But if you want to do well enough you should fully and equally negotiate with students.

\section{Take care of the emotional needs of the students}

The inter subjectivity requires the two sides of the communication regard each other as a real emotional humanbeing. The teacher can't see students coldly as recipients of knowledge, but a lovely child as their children or siblings. Their happiness, sadness, joy or disappointment is the focus of teachers. Teachers should not only help them acquire the knowledge and skills, but also help them enjoy life, form a healthy and positive personality. 
To do this, the teacher should be sensitive to the students' changes in emotion. When the questions raised by the students seem absurd and the other students laugh at him, the teacher can also laugh it off, but immediately make judgments according to the students personality and mental capacity to make a decision quickly whether to encourage $\mathrm{him} / \mathrm{her}$ or to lighten the atmosphere, or break the ice humorously, or to talk to him or her after school to ensure that his / her self-esteem does not hurt?

\section{Multiple rounds of dialogue timely}

The real interaction is not unidirectional, nor a single round. The traditional way in class is that the teacher asks a question, the students or a student answers which is unidirectional .It is a false interaction.

True interaction requires the teacher continue to ask students more questions according to the answer from the students and go on in this way to further the communication with students to deepen the mutual understanding of each other, and make both sides enjoy happiness.

\section{E. Touching the students real life and future career goals}

To make the students interested and think independently, is the questions related with the real life of students and real problem. For example, a teacher of English designs a plan in language practice activities, the requirement for the students is to exchange what their family did last weekend, or what they want to be after graduation, their ideal occupation and what their ideal life is, which is easier to arouse the interest of students, and allow students to truly express their thoughts and feelings.

\section{F. Let the students participate in decision making}

Democracy, equality of education, require both sides, the teacher and the students to have the same right for education decision-making. It seems impossible for the students who are lack of professional knowledge and skills, but students know what they want, what they can do. For example, what the teacher will do in the next class such as the topic choice, the division of class group, group leader candidates, homework and the frequency and way of examination should be fully discussed with the students and reach the consensus. Because, democracy requires teacher not to force students to comply with the specifications and requirements that they have not approved.

\section{CONCLUSION}

Chinese now attaches great importance to the development of Chinese socialist democracy. The construction of democracy requires implement education democracy and democratic education first. One of the most effective forms of democratic educzation is classroom interaction, which is the key of democratic education and the cultivation of innovative talents. In this paper, from intersubjectivity perspective, we discusses the principles and ways of classroom interaction. We feel that the research is not deep enough. We hope we can do more to explore in it.

\section{REFERENCES}

[1] Bowman. Individualized society [M]. Shanghai: the joint publishing company LTD., Shanghai, 2002:153.

[2] Dewey. Democracy and education [M]. Beijing: people's education press, 2001:94-97.

[3] East China normal university. Selected works of Chinese modern education [M]. Beijing: people's education press, 1989:298-300.

[4] Hao Wenwu. Education democratic nature of the intersubjectivity and the way [J]. Journal of education theory and practice, 2009 (2) : 3-6

[5] Ye Lan introduction to education [M]. Beijing: people's education press, 1996:13.

[6] Zheng Zhaoli. Habermas and the significance of Marx's communication category domain and interconnected $[\mathrm{J}]$. Journal of teaching and research, $2000(8)$. 